Contents list available at IJRED website

Int. Journal of Renewable Energy Development (IJRED)

Journal homepage: http://ejournal.undip.ac.id/index.php/ijred

\title{
Pre-treatment of Used-Cooking Oil as Feed Stocks of Biodiesel Production by Using Activated Carbon and Clay Minerals
}

\author{
Rudy Syah Putra ${ }^{*}$, Tatang Shabur Juliantoa, Puji Hartonoa, Ratih Dyah Puspitasaria, and \\ Angga Kurniawan ${ }^{b}$
}

\author{
a Department of Chemistry, Faculty of Mathematics and Natural Sciences, Islamic University of Indonesia, \\ Jl. Kaliurang Km 14.5, Yogyakarta 55584 INDONESIA
}

b Department of Chemical Analysts, Faculty of Mathematics and Natural Sciences, Islamic University of Indonesia, Jl. Kaliurang Km 14.5, Yogyakarta 55584 INDONESIA

\begin{abstract}
Many low-cost feedstock i.e. used-cooking oil (UCO) for the production of biodiesel fuel (BDF) has contained a large amount of water and high proportion of free fatty acids (FFAs). Therefore, a pre-treatment process to reduce the water content $(<0.1 \mathrm{wt} . \%)$ and FFAs $(<2.0 \mathrm{wt} . \%)$ were necessary in order to avoid an undesirable side reactions, such as saponification, which could lead to serious problem of product separation and low fatty acid methyl ester (FAME) yield. . In this study, a pre-treatment process of used cooking oil as a feedstock for the production of BDF by using various adsorbents such as Activated Carbon (AC) and various clay minerals, for example Smectite (S), Bentonite (B), Kaolinite (K), and Powdered Earthenware (PE) were evaluated. The oil obtained from pre-treatment was compared with oil without pre-treatment process. In this study, we reported a basic difference in material ability to the oil, depending on the adsorption condition with respect to the physico-chemical parameters, e.g. refractive index (R), density ( $\rho)$, FFAs, and water content (W). The results showed that the water content and FFAs in the oil has decreased when using AC as an adsorbent compared with clay minerals. However, the refractive index of oil has similar with the oil without pre-treatment process as well; meanwhile, the density of oil has increased after the pre-treatment process by using clay minerals.
\end{abstract}

Keywords: activated carbon, adsorbent, clay minerals, physico-chemical properties, used cooking oil

Article History: Received September 26, 2013; Received in revised form : December 13, 2013; Accepted: January 11, 2014; Available online

How to Cite This Article: Putra, R.S., Julianto, T.S., Hartono, P., Puspitasari, R.D. \& Kurniawan, A. (2014) Pre-treatment of Used-Cooking Oil as Feed Stocks of Biodiesel Production by Using Activated Carbon and Clay Minerals. Int. Journal of Renewable Energy Development, 3(1), 33-35. http://dx.doi.org/10.14710/ijred.3.1.33-35

\section{Introduction}

Biodiesel can be obtained through the transesterification reaction of oil or fat feedstock containing triglycerides with alcohol. Chemically, biodiesel is a mixture of methyl esters with long-chain fatty acids produced from biological sources such as vegetable oils and animal fats or used cooking oil (Leung 2010). Biodiesel as an alternative fuel has some advantages compared to fossil fuel properties, such as the eco-friendly nature, non toxic, renewable, biodegradable, and free of sulfur and other harmful emissions (Guan \& Kusakabe 2009).

Vegetable oil (i.e., palm oil) is raw minerals that are abundant in Indonesia because of the regular consumption of Indonesian people to palm cooking oil. Almost all types of cuisine in the country needs to be cooked by using palm oil in the processing, so that the need for cooking oil has increased every year. In 2011 the consumption of cooking oil in Indonesia stands at 7.1 million tons and by 2013 this is reached 8.5 million tons (Indexmundi 2013). Therefore, the amount of used-cooking oil also increased as raw material for

\footnotetext{
* Corresponding author:Tel. +6281327709104

Email: rudy.shahputra@uii.ac.id
} 
Citation: Putra, R.S., Julianto, T.S., Hartono, P., Puspitasari, R.D. \& Kurniawan, A. (2014) Pre-treatment of Used-Cooking Oil as Feed Stocks of Biodiesel Production by Using Activated Carbon and Clay Minerals. Int. Journal of Renewable Energy Development, 3(1), 33-35, doi: 10.14710/ijred.3.1.33-35

P a g e | 34

biodiesel. In addition, the utilization of used-cooking oil as biodiesel diminishes the problem of contamination, because the reusing of these greases can reduce the burden of the government in disposing of the waste, maintaining public sewers, and treating the oil wastewater.

Use-cooking oils have properties different from those of refined and crude oils. The high temperatures of typical cooking processes and water from the foods accelerate the hydrolysis of triglycerides and increase the free fatty acid content in the oil. Also, problem with the stability of the mixtures and increases in the peroxide value are observed. Likewise, the viscosity, iodine value, saponification value, and density are different when refined and crude oils are used (Encinar et al. 2005).

High concentrations of glycerol in biodiesel can cause problems during storage due to its separation, and in usage by forming deposits on injection nozzles and promoting an increase in aldehyde emissions (Mittelbach 1996). The presence of water in the biodiesel can cause engine corrosion or side reactions with glycerides to produce soaps and glycerol.8 Soaps and free fatty acids cause the deterioration of certain components of engines (Faccini et al. 2011) Thus, the pre-treatment used-cooking oil that content of water amount and free fatty acid are essential for the viability of biodiesel use and also for the choice of the raw minerals employed in the transesterification process.

In the present study aimed to investigate the use of activated carbon and clay minerals (e.g. smectite, bentonite, kaolinite and powdered earthenware) as adsorbent for pre-treatment of used-cooking oil as a source of biodiesel production. Furthermore, the adsorption condition with respect to the physicochemical parameters, e.g. refractive index (R), density $(\rho)$, FFAs, and water content $(\mathrm{W})$ were measured.

\section{Materials and Methods}

\subsection{Materials}

Used-cooking oil was received from home industry activities around of Universitas Islam Indonesia (UII) campus. Bentonite, kaolinite, and smectite were purchased from Wako Chemicals Ltd., Japan and activated carbon from Merck, Germany. Powdered earthenware was prepared by crushed the traditional earthenware. Other chemicals were purchased from Merck, Germany.

\subsection{Experimental procedures}

The process involves direct filtration by using filter paper. First filtration was carried out to remove solid particle from oil and the second one was adsorption process by using adsorbent. Adsorption process was carried out in $100 \mathrm{ml}$ beaker glass. $50 \mathrm{~g}$ of used-cooking oil was heated until $100^{\circ} \mathrm{C}$. After that, a $5 \mathrm{~g}$ of activated carbon was poured into the oil and then stirred for 80 minutes. The mixture was then filtered and the filtrate analyzed for its physico-chemical properties including density, refractive index, water content, and free fatty acids (FFAs), respectively. A similar procedures were also prepared for bentonite, smectite, kaolinite and powdered earthenware.

\subsection{Analysis of used-cooking oil}

The analytical methods used to determine the characteristics of the oil are basically those recommended by the SNI (National Standard of Indonesia). The following properties of the usedcooking oil after pre-treatment process were determined: density (pycnometry), refractive index (open prism refractometry), free fatty acid (alkaline titration), and water content (different weight).

\section{Result and Discussion}

The qualities of pre-treatment of used-cooking oil were determined by physico-chemical analysis and the results were shown in the Fig. 1 for FFAs (\%) and water content (\%) and Tab. 1 for density $(\mathrm{g} / \mathrm{ml})$ and refractive index, respectively. Fig. 1 shows that the pre-treatment process for each adsorbent was able to reduce of water content and free fatty acid (FFA) in the oil significantly, except for powdered earthenware material. High decreasing of water content $(<0.1 \%)$ and FFAs $(0.23 \%)$ in the used-cooking oil was achieved when activated carbon was used as an adsorbent compared with clay minerals.

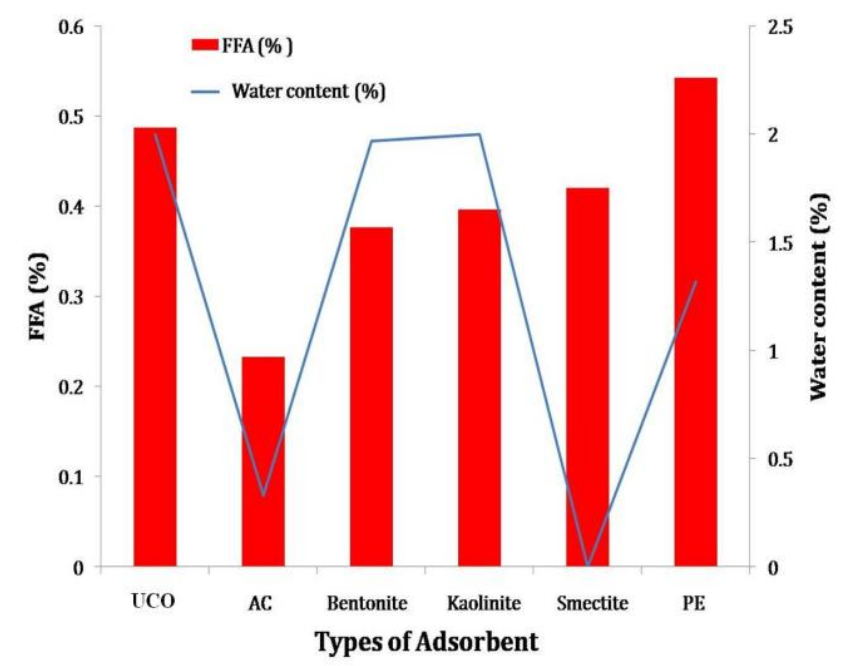

Fig. 1 The FFAs and water content for used-cooking oil after adsorption process by using various adsorbent compared with the oil without pre-treatment process 
Table 1 Physico-chemical parameters used cooking oil purification results

\begin{tabular}{|c|c|c|c|c|c|c|}
\hline \multirow{2}{*}{ Parameters } & \multirow{2}{*}{ UCO } & \multirow{2}{*}{$\begin{array}{c}\text { Activated } \\
\text { carbon }\end{array}$} & \multicolumn{4}{|c|}{ Clay minerals } \\
\hline & & & Bentonite & Kaolinite & Smectite & PE \\
\hline Density (g/mL) & 0.828 & 0.830 & 0.931 & 0.930 & 0.931 & 0.935 \\
\hline Refractive index & 1.462 & 1.463 & 1.463 & 1.462 & 1.462 & 1.463 \\
\hline
\end{tabular}

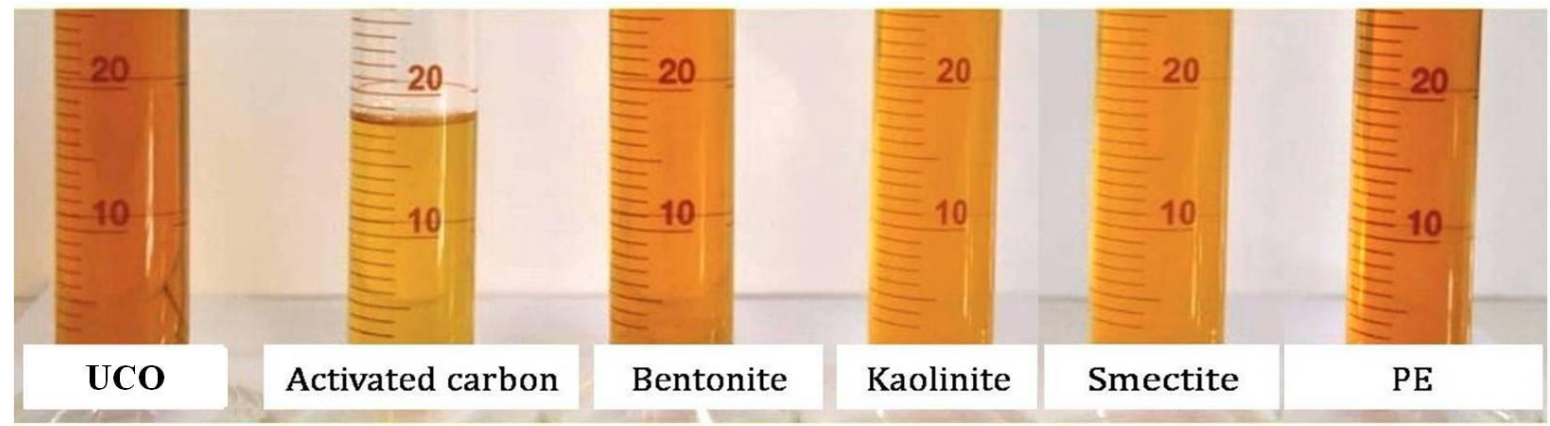

Fig. 2 Transparency of oil after adsorption processs by using various adsorbents

Several studies have recommended that the free fatty acid content in the oil should have less than $0.5 \%$ and also be free of water or less than $1 \%$, so that the catalyst will not react with water that would eliminate the ability of catalytic process (Freedman et. al. 1984). For the clay material, the lowest percentage of those properties was occurred when using powdered earthenware (PE) as an adsorbent. Tab. 1 shows that the refractive index of used-cooking oil for each adsorbent after pre-treatment process was not high different compared with the oil without pre-treatment process. Meanwhile, the high density of the oil after pretreatment process was occurred because of solubility effects of clay material in the oil. Fig. 2 shows the transparency of used-cooking oil after adsorption process by using various adsorbents. Activated carbon gives the best results for the clearness of the oil compared with the clay minerals. The treatment of oil by using smectite has given a lighter colour than the other clay minerals. However, the refractive index in the Tab. 1 was not reflecting for these results. Therefore, it is concluded that the adsorption process does not significantly affect the value of the refractive index.

\section{Conclusion}

The pre-treatment of used-cooking oil by using activated carbon and clay minerals affected to the oil properties such as free fatty acid, water content, and specific gravity. The pre-treatment process by using activated carbon gives a good quality of used-cooking as a feed stock of biodiesel production compared with clay minerals.

\section{Acknowledgements}

Authors would like thank to DIKTI for financial support so that this research can be accomplished. The author also would like thank to all those who helped the completion of this research.

\section{References}

Encinar, J.M., Gonza' lez, J.F. \& Rodríguez-Reinares, A. (2005) Biodiesel from used frying oil variables affecting the yields and characteristics of the biodiesel, Industrial Engineering Chemical Research, 44, 5491 - 5499.

Faccini, C.S., Espinosa da Cunha, M., Moraes, M.S.A., Krause, L.C., Manique, M.C., Rodrigues, M.R.A., Benvenutti, E.V. \& Caramão, E.B. (2011) Dry washing in biodiesel purification: a comparative study of adsorbents, Journal of Brazilian Chemical Society, 22(3), 558-563.

Freedman, B., Pryde, E.H. \& Mounts, T.L. (1984) Variables affecting the yields of fatty esters from transesterfied vegetable oils, Journal of the American Oil Chemists Society, 61(10), 1638-1643.

Guan, G. \& Kusakabe, K. (2009) Synthesis of biodiesel fuel using an electrolysis method, Chemical Engineering Journal, 153, 159-163.

Leung D.Y.C., Wu X. \& Weung M.K.H. (2010) A review on biodiesel production using catalyzed transesterification, Applied Energy, 87, 1083-1095.

Mittelbach, M. (1996) Diesel fuel derived from vegetable oils, VI: Specifications and quality control of biodiesel, Bioresource Technology, 56, 7-11.

Indexmundi (2013) Indonesia Palm Oi Domestic Comsumption per Year. http://indexmundi.com/agriculture/ (accessed date 6 Januari 2014) 